\title{
Quality of Dental Care among Elderly in Benha City
}

\author{
Magda M. Mohsen ${ }^{1}$, Hanaa A. Abd EL Megeed ${ }^{2}$, Doaa M. S. Elsayed \\ Mervat E. Abd El-Rhaman ${ }^{4}$ \\ Professor of Community Health Nursing-Faculty of Nursing -Menoufia University-Egypt ${ }^{1}$, \\ Assistant Professor of Community Health Nursing-Faculty of Nursing-Benha University ${ }^{2}$, \\ Lecturer of Community Health Nursing, Faculty of Nursing-Benha University ${ }^{3}$ and Supervisor at Quissna \\ Hospital $^{4}$, Egypt $^{2,3 \& 4}$
}

\begin{abstract}
Background: Oral health is a state of being free from mouth of pain, oral and throat cancer, oral infection and sores, periodontal (gum) disease, tooth decay, tooth loss, and other diseases and disorders that limit an individual's capacity in biting, chewing, smiling, speaking, and psychosocial wellbeing.

Aim of this study was to determine quality of dental care among elderly in Benha City.

Design: A descriptive analytical research design was used.

Setting: A multistage random selection of twohospitals; out-patient dental clinics in Benha University Hospital and Teaching Hospital at Benha City, Egypt. The

sample: A simple random sample of 150 elderly was selected in this study.

Tools: tool(1): An interviewing questionnaire: to assess elderly socio-demographic characteristics of the studied elderly and their knowledge about oral health. Tool(2): Observational check-list of dental care and dental health, Tool(3): Elderly attitude toward dental healthlikert scale to assess elderly attitude toward dental health.

Results, $86.7 \%$ of the studied elderly had correct knowledge about the important teeth, whereas $98.0 \%$ of studied sample agreed that the attitude of hot food after cold food harm teeth and57.3\% of studied elderly had good practice about washing the teeth.

Conclusion: There were statistically significant relation between the studied elderly attitude and sociodemographic data. There were no statistically significant relation between studied elderly's practice and sociodemographic. Also, there was no statistically significant relation between studied elderly's knowledge and socio-demographic data.
\end{abstract}

Recommendation, health education program for elderly regarding importance of oral health practices rather than providing only knowledge, further research about obstacles of elderly's oral health.

Keywords: Oral Health Knowledge \&Practices, Quality of life, Elderlyoral disease.

\section{Introduction}

Aging is a natural process; this process is a biological reality which has its own dynamic, largely beyond human control. Elderly are individuals over 65 years old who have functional impairments, as a normal inevitable biological phenomenon. Elders above 65 years (old age) have health problems as a result of aging process, which calls for special considerations [1]. According to the WHO, the global population is increasing at the annual rate of $1.7 \%$, while the population of those over 65 years is increasing at a rate of $2.5 \%$. Both the developed, as well as the lesser-developed countries, are expected to experience significant shifts in the age distribution of the population by 2050. The fastest growing population segment in most countries is the elder people than 80 years, which according to the United Nations estimates will make up nearly $20 \%$ of the world's population [2].

People aged 65-74 years are the new or young elderly who tend to be relatively healthy and active. People aged 75-84 years are the old or mid-old, who vary from those being healthy and active to those managing of chronic diseases. People 85 years and older are the oldest-old, who tend to be physically frailer. This last group is the fastest-growing segment of the older adult population [3].

Successful ageing is synonymous with maintenance of quality of life. From a dental perspective this involves controlling oral disease and restoring damaged tissue, with an underlying premise that treatments effective in achieving those goals will consequently produce improved oral function, comfort and social wellbeing. Elderly people are the most group high risk of oral diseases. The most common problem is tooth loss. Tooth loss is associated with reduced quality of life, and has adverse consequences for social interaction and psychological health. Edentulous elderly suffer more pain and discomfort, and experience greater difficulties chewing and eating than their dentate counterparts [4]. 
Oral health is an important and often overlooked component of an older person's general health and well-being." The elderly are not healthy without good oral health" Oral health can affect general health in very direct ways. Oral health problems can cause pain and suffering as well as difficulty in speaking, chewing, and swallowing. These problems can also be a complication of certain medications used to treat systemic diseases. In addition, the treatment of systemic diseases can be complicated by oral bacterial infections [5].

Poor oral health places an elderly at higher risk for nutritional deficiency.Frail elders with poor teeth take little pleasure in eating a diet that was consists primarily soft, puréed, or mashed foods.This can result in self-imposed restrictions in food selection that can in turn contribute to a low intake of essential nutrients. This leads to a state of under-nutrition. Poor nutrition is a factor in xerostomia and age-associated physiological changes that affect digestion, absorption, and taste perception.This has a negative impact on food selection and appetite. Xerostomia, which affects about 20 percent of elders, has a negative effect on appetite and oral comfort. Xerostomia affects the ability to chew and form a food bolus. This leads to avoidance of certain foods, resulting in nutritional inadequacies [6].

Oral disease can cause many problems one of these problems is pneumonia can be a life-threatening infection, especially in the elderly, and it is a significant cause of morbidity and mortality. Twenty-one species of microorganisms were detected in the dental plaques. Bacteria that commonly cause respiratory infection colonized in dental plaques of the aged, dependent subjects. Therefore, dental plaques must be considered a specific reservoir of colonization and subsequent aspiration pneumonia in dependent elderly [7].Oral diseases and dissatisfaction with the mouth and teeth can affect general health and QOLand the connection between oral health and QOL is often multidimensional. It can be seenfrom a professional point of view and from the subjects' point of view, which do not alwayscorrelate [8].

Quality is represented as the interaction of human needs and the subjective perception of their fulfillment, mediated by the opportunities available to meet the needs. These meet the human needs now and in the future [9].Quality of life is the degree to which a person enjoys the important possibilities of life. Possibilities result from the opportunities and limitations each person has in life and reflect the interaction of personal and environmental factors. Enjoyment has two components: the experience of satisfaction and the possession or achievement of some characteristic. Quality is a characteristic allowing for excellence. The QOL is defined as the physical, emotional, intellectual, or cultural satisfaction in a person's everyday life. This concept as used in health care delivery defines the standard by which outcomes for the total patient can be assessed. For healthy persons, optimal vision and hearing, healthy skin, optimal nutrition with palatable and healthful food. An appropriate health care approach and life style regimen all add up two the basics necessary for quality of life[10, 11\& 12]. Quality of Oral health is defined as state of being free from chronic mouth and facial pain, oral and throat cancer, oral sores, birth defects such as cleft lip and palate, periodontal (gum) disease, tooth decay and tooth loss, and other diseases and disorders that affect the oral cavity[13].

Dental care is vital to maintain natural teeth and enhance the quality of life for elderly. Good oral health is essential for healthy ageing. A healthy mouth will enhance the general health and quality of life, and assist the elderly to ability to eat and talk comfortably. With older age, there is greater chance the general health and medications will affect the health of the teeth, mouth and gums. Poor oral health causes gum disease, tooth loss and tooth decay If the mouth is unhealthy, bacteria may build-up and spread infection to other parts of the body causing lung infections, heart disease or a stroke [14].

Community Health Nurses play a key role in promoting oral health among the elderly and considered an important component of a successful oral hygiene program. The education and skills of dental hygienists enable them to act as consultants for procedure and program development, identify oral care needs of residents, develop individualized care plans, provide clinical hygiene treatment, make referrals to dentists, and implement facility oral health programs. CHNs are best suited to regulate and enforce oral hygiene delivery by care aides. Communication should remain open between nurses and care aides to address [15].

The Community health nurses teach the elderly how they take care of their dentures by removing and rinse dentures after eating, run water over your dentures to remove food debris and other loose particles, place a towel on the counter or in the sink or put some water in the sink so the dentures won't break if you drop them, handle the dentures carefully, be sure you don't bend or damage the plastic or the clasps when cleaning, clean the mouth after removing the dentures, use a soft-bristled toothbrush on natural teeth and gauze or a soft toothbrush to clean the tongue, cheeks and roof of the mouth $[16,17 \& 18]$.

\section{Significance of the study:}

Elderly people are one of the most rapidly growing age groupsin the United States. In 2010, census data indicated therewere 40.4 million individuals 65years of age and older. By the year 2050, the number ofAmericans aged 65 will double, to a projected 88.5 million[19].Elderly people are vulnerable individuals who are at risk for food insecurity.Physical health has a significant effect on nutrient intake and poor nutritional status reduction in physical health. These lead to inability to do daily hygiene such as oral care. oral disease lead 
to malnutrition, underweight, overweight, obesity, food insecurity, and hungerarelinked to decreased quality of life, increased morbidity and premature mortalityin theelderly [20]. In Egypt, the elderly are the fastest growing segment of the population. In December 2008, the Information Decision Support Center published the first comprehensive study of the elderly in Egypt. According to the report, in1986, 5\% of Egyptians were age 60 and older. In 2015 they about $11 \%$ of the population and in 2050 they will make up over a fifth [21].

\section{Aim Of Study}

This study aimed to determine quality of dental care among elderly in Benha City.

\section{Research Questions}

1-What is the level of elderly's knowledge, attitude and practice regarding dental care?

2- What is the dental health condition among elderly?

3-What are the predisposing factors that leading to dental problems among elderly?

4-Is the elderly taking care of their teeth?

5-Is there a relation between socio demographic characteristics of elderly people and dental care?

\section{Subjects And Methods .III}

Design: A descriptive research design was used to achieve the desired aim of study.

Setting: The study was conducted by a multistage random selection of two hospitals. Thenthe study was conducted at out-patient dental clinics in Benha University Hospital and Teaching Hospital at Benha City, Egypt.

Sample: A simple random sample of 150 elderly was selected in this study. It involved all elderly attending the out patients clinics in University Hospital and Teaching Hospital at Benha City start from beginning of March 2015 to end of August 2015 over 6 months who will fulfill the following criteria:-

-Diagnosed with dental problems

-Both sexes of elderly people 65 years old and more.

\section{Tools of data collection:}

Tool(1): Structured Interviewing Questionnaire :-

It was developed by the investigator, based on reviewing the related literatures. It was written in simple Arabic language and includes the followingparts:-

The first part:Socio-demographic characteristics of the studied elderly: This part included eight items related to age, gender, education, occupation and monthly income.

The second part: Health status of the elderly at the present time, these items included four questions.

The third part: Elderly's knowledge about dental health and dental problems, it was divided into two sections:

The first sectionwas elderly's knowledge about teeth which included six closed ended questions (1-6); the importance of teeth, number of teeth, types and composition of teeth, meaning of fluoride and importance of fluoride.

The second section included elderly knowledge about dental problems, which divided into eight items, elderly knowledge about dental caries (included five questions 1-5), elderly knowledge about gingivitis (included four questions 1-4), elderly knowledge about dental injuries (included five questions 1-5), elderly knowledge about dental loss (included one questions), knowledge about dental discoloration (included two questions), knowledge about nutrition (included three questions 1-3), elderly knowledge about dental care and these item (included five questions), practice of elderly towards treating dental disease (included thirteen questions).

\section{Tool (2): Observational check list of dental care and dental health:-}

Assess dental health and dental care among elderly and these tool included fourteen items, odor included two items, condition of mouth included four items, tongue included four items, facial edema, dental caries which included three items, losing teeth included three items, color of teethincludes ;three items, gumincluded four items, teeth pain with hot food, teeth pain with cold food, problem with speaking, shy and avoid smiling, difficult chewing food and difficult swallowing food and these answer of these items by yes or no.

\section{Tools (3): Elderly's Attitude toward Dental HealthLikert scale:-}

To assess elderly's attitude toward dental health and this scale consisted of sixteen items; it was adopted from Delaney (2004)[22].

\section{Scoring system:}

A score for each answer on questions of attitude was given as follows: 


$$
\begin{array}{ll}
- & 2=\text { Agree } \\
- & 1=\text { Sometimes } \\
- & 0=\text { Dis agree }
\end{array}
$$

The total score of attitude $=32$

The attitude was considered satisfactory if total attitude score $>50 \%$ and considered unsatisfactory if $<50 \%$

Content validity: The tool validity was revised by five experts from experts from community health nursing to assess content and face validity, relevance of the tools for assessment what it should assess, comprehensiveness, understanding and applicability.

Reliability: Reliability was applied by the investigator for testing the internal consistency of the instruments, by administration of the same instruments to the same of subjects under similar condition twice with an interval 2 weeks. Answers from reported testing were compared (test-re-test reliability). The reliability of the study instrument was tested using Cronbach Alpha. It amounted to be $\mathrm{R}=0.81$ indicating good reliability of the instrument. It is acceptable inters the consistency.

Pilot study: A pilot study was carried out on sample 10\% elderly's taken from the target population to ensure clarity and applicability of the tools and these elderly's was not included in the sample. The modifications were done and then the final formats were developed.

Data Collection Procedure:

- Study Period for Data Collection:-Data were collected from beginning of March to the end of August 2015.

- Approval: A formal approval was obtained through official letter from the Dean Faculty of Nursing, Benha University to the Directors of the Benha University Hospital and Teaching Hospital conduct the study. The letter included the study title, aim and setting where the study was conduct. Oral consent from elderly was taken.

- Tools Development:

Tools Developments A. Validity of the tool: - Tools were checked by a panel of experts in community health nursing. The corrections were done accordingly based on their response.

B. Reliability of the toolwas done by test-retest for measuring internal consistency.

C. Pilot: study was performed to test the practicality and applicability of the questionnaire.

- Ethical considerations: Permission has been obtained from each elderly before conducting the interview. Elderly were informed about the purpose, benefits of the study and that their participation is voluntary. Also, they were informed that they have to withdraw from the study at any time without giving reason. Privacy and confidentiality were assured, ethics, values, culture and beliefs were respected.

- The investigator attended two days per week from 9.00 AM to12.00 PM; those days were (Sunday, Thursday).

- The average minutes of interviewed elderly take about 20 to 30 minutes to fill the questionnaire depending upon their understanding and response.

- The respondents filled the questionnaires, in the presence of the investigator all the time to clarify any ambiguities and answer any queries and collect the questionnaire.

- In addition observational check list was filled by the investigator.

\section{Statistical Analysis:}

The clinical data were recorded on a report form. These data were tabulated and analyzed using the computer program SPSS (Statistical package for social science) "SPSS version 20", which was applied to calculate:-

1. The descriptive statistics were calculated for the data in the form offrequencies and percentages mean.

2. Analytical statistics; test statistical significance and association by using Chi - square test (X) was used to study association between two qualitative variables and matrix correlation to detect the relation between the variables.

3. In the statistical comparison between the different groups, the significance of difference was tested using one of the following tests:-

a. -Student's t-test:- Used to compare mean of two groups of quantitative data.

b. Z test:- used to compare proportion between two groups of qualitative data.

The observation difference and associations were considered as following:

Highly significant (HS) $\quad \mathrm{P}<0.001$

Significant $(\mathrm{S}) \quad \mathrm{P}<0.05$

Not Significant (NS) $\quad \mathrm{P}>0.05$ 


\section{Results}

Table (1): Showed that, $58.7 \%$ of studied elderly their age ranged from 65 to less than 70 years old, with mean age $72.1 \pm 5.23,69.3 \%$ of elderly were male, $50.7 \%$ of them could read and write, $88.7 \%$ of them didn't work, 74.7\% had enough income, $62.7 \%$ lived in rural area, $69.3 \%$ lived in separate house.

Figure (1): Showed that, $61.3 \%$ of the studied sample had dental loss as dental disease, $50 \%$ had gum inflammation, $43.3 \%$ had broken teeth, $34.7 \%$ had dental caries and $21.3 \%$ have discoloration of teeth.

Table (2): This table clarified that, regarding meaning dental caries $70 \%$ study sample know the correct answer, $74 \%$ know cause of caries, $56 \%$ know complains, $48.7 \%$ know all foods that cause dental pain and $74 \%$ of sample understand how to protect teeth from dental caries.

Table (3): Showed that regarding practices towards treating dental diseases, $57.3 \%$ of elderly washing teeth, $50 \%$ washing teeth once daily, while $42.6 \%$ never have regularity in washing teeth, $38.4 \%$ washing teeth before sleep and $62.8 \%$ using brush in dental wash, $48.1 \%$ change brush every 3 month, $88.9 \%$ clean tongue after brushing tooth. Also $62 \%$ of study sample visiting dentist in case of dental problem, $51.6 \%$ visit a dentist since one year ago, $44.1 \%$ using removal as dentist procedure, $44 \%$ use medical syrup as mouth gurgle, $36.8 \%$ using kronful oil as traditional method, $35.3 \%$ using glivanan as analgesics.

Table (4): Showed that, $70 \%$ of elderly have normal mouth smell, $44.7 \%$ have wet mouth condition $62.7 \%$ have normal tongue and $75.3 \%$ had no facial swelling. $41.3 \%$ didn't have dental caries. $78.7 \%$ have molar loss. 48.7\% have yellow teeth in color $51.3 \%$ have red gums, $88.7 \%$ have pain with cold food, $58 \%$ have pain with hot food, $60 \%$ have problem with speaking, also 54\% have shy and avoid smiling and also 54\% have hard swallowing of food, $68.7 \%$ have pain with chew hard food chewing.

Table (5): Indicated that, $66.7 \%$ agreed that eating sugary food is harmful to teeth, $80.7 \%$ agreed that dental wash keep it healthy, 52.7 agreed the necessity of washing teeth daily be for bedding, $65.3 \%$ had thought of necessity of visiting dentist with dental pain, $58.0 \%$ agreed that healthy teeth means healthy body, $63.3 \%$ agreed that milk, cheese and fruits keep teeth healthy, $77.3 \%$ agreed that brushing teeth keep it healthy, $53.3 \%$ agreed that increasing washing teeth make it healthier, $98 \%$ agreed that hot food after cold harm teeth.

Table (6):Demonstrated that; the mean $\pm \mathrm{SD}$ of unsatisfactory elderly regarding level of attitude toward dental health was $40.42 \pm 8.5$ and mean of \pm SD of satisfactory elderly was $65.75 \pm 1.92$. Also, there were highly statistical significant difference toward elderly satisfaction and un-satisfaction regarding elderly total attitude toward dental health where $\mathrm{p}=(0.001)$.

Table (7):Shows that; regarding relation between elderly sociodemographic characteristic and their attitude, there were highly status statistical significant relation between elderly total attitude levels and their sex, educational levels, working, monthly income and residence with ( $\mathrm{p}=0.003,0001,0.002,0.001,0.001)$ respectively. Table (8): showed that, regarding relation between elderly socio demographic characteristic and their knowledge there were highly no statistical significant relation between elderly total knowledge levels and their; age, sex, educational levels, working, monthly income, residence and type of housing with $\mathrm{p}=(0323,0195,0.713,1.0,0.921,0.09)$ respectively.

Table (9):This table shows that relation between practice levels regarding socio demographic data. Regarding age $59.1 \%$ aged from $65-70 y$ ears are unsatisfactory to practice, $57.1 \%$ were satisfactory. According to sex $67 \%$ of male were unsatisfactory, $77.1 \%$ weresatisfactory. According education level $53 \%$ read and write were unsatisfactory, $42.9 \%$ weresatisfactory. There was statistical significant difference between satisfactory and unsatisfactorypractice where $\mathrm{p}=0.049 .67 \%$ living in separate house are unsatisfactory topractice, $77.1 \%$ weresatisfactory to practice.

Figure (2): Shows that, mean $\pm \mathrm{SD}$ of knowledge of studied sample was $85.79 \pm 13.51$, mean $\pm \mathrm{SD}$ of attitude were $47.35 \pm 13.48$ and mean $\pm \mathrm{SD}$ of practice is $62.83 \pm 14.9$.

Table (1) Distribution of elderly regarding socio-demographic data(n=150)

\begin{tabular}{|c|c|c|}
\hline Socio-demographic data & No. & $\%$ \\
\hline \multicolumn{3}{|l|}{ Age in years } \\
\hline 65 & 88 & 58.7 \\
\hline $70-$ & 47 & 31.3 \\
\hline $75+$ & 15 & 10.0 \\
\hline \multirow{2}{*}{\multicolumn{3}{|c|}{$\begin{array}{l}\text { Mean } \pm \text { SD } \\
\text { Sex }\end{array}$}} \\
\hline & & \\
\hline Male & 104 & 69.3 \\
\hline Female & 46 & 30.7 \\
\hline \multicolumn{3}{|l|}{ Education level } \\
\hline Read and write & 76 & 50.7 \\
\hline Primary education & 38 & 25.3 \\
\hline Secondary education & 17 & 11.3 \\
\hline University education and more & 19 & 12.7 \\
\hline Occupation & & \\
\hline
\end{tabular}


Quality of Dental Care among Elderly InBenha City

\begin{tabular}{|l|l|l|}
\hline Yesworking & 17 & 11.3 \\
\hline Not working & 133 & 88.7 \\
\hline \multicolumn{1}{|c|}{ Monthly income } & & \\
\hline Enough and saving & 14 & 9.3 \\
\hline Just enough & 112 & 74.7 \\
\hline Not enough & 24 & 16.0 \\
\hline Residence & & \\
\hline Rural & 94 & 62.7 \\
\hline Urban & 56 & 37.3 \\
\hline Housing type & & \\
\hline Separate & 104 & 69.3 \\
\hline Shared & 46 & 30.7 \\
\hline
\end{tabular}

Figure(1): Distribution of elderly regarding their dental disease

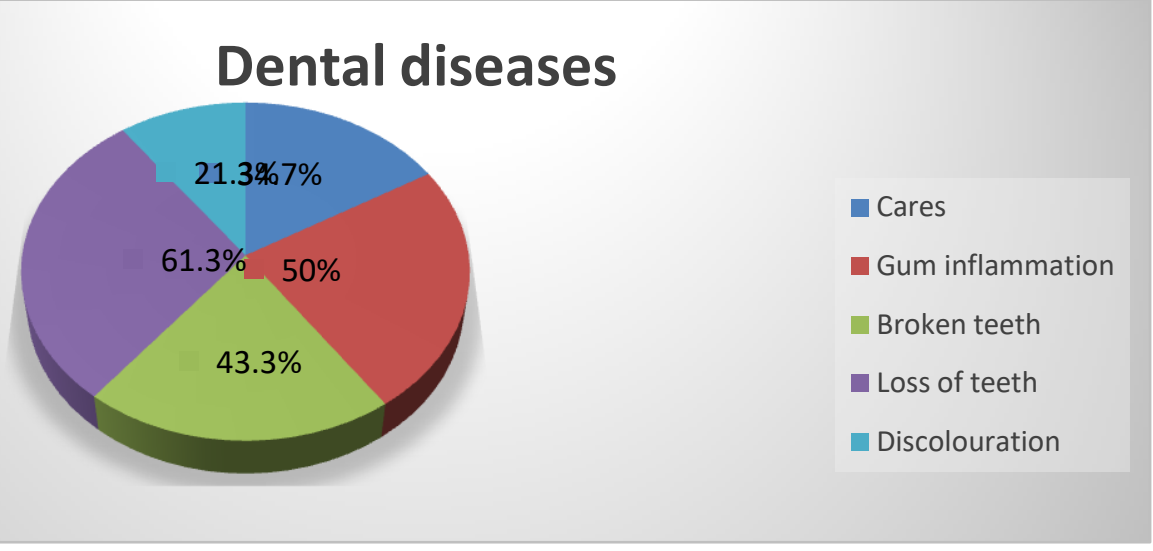

Table (2): Distribution of elderly regardingknowledge about dental caries( $n=150)$.

\begin{tabular}{|l|l|l|}
\hline Knowledge about dental caries & No. & \% \\
\hline \hline Meaning of dental caries & & \\
\hline Bacteria presence in mouth for long period & 5 & 3.3 \\
\hline More common in childhood & 21 & 14.0 \\
\hline All & 105 & 70.0 \\
\hline Don't know & 19 & 12.7 \\
\hline Causes of dental caries & & \\
\hline Sugary food & 15 & 10.0 \\
\hline Soft drinks & 1 & 0.7 \\
\hline Less care of dental health & 10 & 6.7 \\
\hline All & 111 & 74.0 \\
\hline Don't know & 13 & 8.7 \\
\hline Complains of elderly with dental caries & & \\
\hline Pain & 22 & 14.7 \\
\hline Teeth discoloration & 11 & 7.3 \\
\hline Inability of eating & 10 & 6.7 \\
\hline Mild fever & 1 & 0.7 \\
\hline All & 84 & 56.0 \\
\hline No complain & 22 & 14.7 \\
\hline Foods causing dental pain & & \\
\hline Sugary food & 26 & 17.3 \\
\hline Hot food & 22 & 14.7 \\
\hline Cold food & 47 & 31.3 \\
\hline All food types & 73 & 48.7 \\
\hline Teeth protectionfrom dental caries & & \\
\hline Fruits and veg intake & 3 & 2.0 \\
\hline Food rich with calcium & 4 & 2.7 \\
\hline Avoid sugary food & 18 & 12.0 \\
\hline Regular teeth washing & 7 & 4.7 \\
\hline All & 111 & 74.0 \\
\hline Don't know & 7 & 4.7 \\
\hline & & \\
\hline
\end{tabular}


Table (3): Distribution of elderly regardingpractices towards treating dental problems $(\mathrm{n}=150)$.

\begin{tabular}{|c|c|c|}
\hline Practices towards treating dental problems & No. & $\%$ \\
\hline \multicolumn{3}{|l|}{ Washing teeth } \\
\hline Yes & 86 & 57.3 \\
\hline No & 64 & 42.7 \\
\hline \multicolumn{3}{|l|}{ How many times of washing (86) } \\
\hline Once & 43 & 50.0 \\
\hline Twice & 29 & 33.7 \\
\hline More & 14 & 16.3 \\
\hline \multicolumn{3}{|l|}{ Degree of regularity in washing teeth } \\
\hline All times & 18 & 12.0 \\
\hline Most of times & 22 & 14.7 \\
\hline Sometimes & 22 & 14.7 \\
\hline Rarely & 24 & 16.0 \\
\hline Never & 64 & 42.6 \\
\hline \multicolumn{3}{|l|}{ Time of dental wash (86) } \\
\hline At the morning & 17 & 19.8 \\
\hline After meals & 9 & 10.5 \\
\hline Before sleep & 33 & 38.4 \\
\hline Others & 27 & 31.4 \\
\hline \multicolumn{3}{|l|}{ Using brush in dental wash (86) } \\
\hline Yes & 54 & 62.8 \\
\hline No & 32 & 37.2 \\
\hline \multicolumn{3}{|l|}{ Time of brush change (54) } \\
\hline Every month & 5 & 9.3 \\
\hline Every $2 \mathrm{~m}$ & 15 & 27.8 \\
\hline Every $3 \mathrm{~m}$ & 26 & 48.1 \\
\hline Don’t know & 8 & 14.8 \\
\hline \multicolumn{3}{|l|}{ Tongue clean after brushing tooth $(54)$} \\
\hline Yes & 48 & 88.9 \\
\hline No & 6 & 11.1 \\
\hline \multicolumn{3}{|l|}{ Visiting dentist in case of dental problems } \\
\hline Yes & 93 & 62.0 \\
\hline No & 57 & 38.0 \\
\hline \multicolumn{3}{|l|}{ Last visit to dentist } \\
\hline A week ago & 7 & 7.5 \\
\hline $2 \mathrm{w}$ ago & 9 & 9.7 \\
\hline A month ago & 14 & 15.1 \\
\hline A year ago & 15 & 16.1 \\
\hline$>1 \mathrm{y}$ & 48 & 51.6 \\
\hline \multicolumn{3}{|l|}{ Dentist procedure (93) } \\
\hline Medicine prescription & 30 & 32.3 \\
\hline Removal & 41 & 44.1 \\
\hline Filling & 19 & 20.4 \\
\hline Nerve killing & 1 & 1.1 \\
\hline Teeth fixing & 2 & 2.2 \\
\hline \multicolumn{3}{|l|}{ Using mouth gurgle } \\
\hline Salt with warm water & 30 & 20.0 \\
\hline Medical syp & 66 & 44.0 \\
\hline Not & 54 & 36.0 \\
\hline \multicolumn{3}{|l|}{ Using traditional method (57) } \\
\hline Baraka seed & 12 & 21.1 \\
\hline Kronful oil & 21 & 36.8 \\
\hline Olibove oil & 20 & 35.1 \\
\hline Tobacco & 4 & 7.0 \\
\hline \multicolumn{3}{|l|}{ Using analgesics } \\
\hline Aspirin & 45 & 30.0 \\
\hline Ketofan & 53 & 0.0 \\
\hline Glivanan & 0 & 35.3 \\
\hline No & 52 & 34.7 \\
\hline
\end{tabular}


Table (4): Distribution of elderly regardingdental health care assessment

\begin{tabular}{|c|c|c|}
\hline Dental health and care assessment & No. & $\%$ \\
\hline \multicolumn{3}{|l|}{ Mouth smell } \\
\hline Bad & 45 & 30.0 \\
\hline Normal & 105 & 70.0 \\
\hline \multicolumn{3}{|l|}{ Mouth condition } \\
\hline Wet & 67 & 44.7 \\
\hline Dry & 21 & 14.0 \\
\hline Inflamed & 56 & 37.3 \\
\hline Red & 48 & 32.0 \\
\hline \multicolumn{3}{|l|}{ Tongue } \\
\hline Normal & 94 & 62.7 \\
\hline Enlarged & 19 & 12.7 \\
\hline Small & 14 & 9.3 \\
\hline With pathos & 23 & 15.3 \\
\hline \multicolumn{3}{|l|}{ Facial swelling } \\
\hline Yes & 37 & 24.7 \\
\hline No & 113 & 75.3 \\
\hline \multicolumn{3}{|l|}{ Dental caries } \\
\hline Not & 62 & 41.3 \\
\hline Superficial & 30 & 20.0 \\
\hline Deep & 58 & 38.7 \\
\hline \multicolumn{3}{|l|}{ Tooth's loss } \\
\hline Teeth loss & 92 & 61.3 \\
\hline Canines loss & 116 & 77.3 \\
\hline Molars loss & 118 & 78.7 \\
\hline \multicolumn{3}{|l|}{ Dental color } \\
\hline White & 30 & 20.0 \\
\hline Yellow & 73 & 48.7 \\
\hline Brown & 47 & 31.3 \\
\hline \multicolumn{3}{|l|}{ Gums } \\
\hline Red & 77 & 51.3 \\
\hline Edema & 34 & 22.7 \\
\hline Bleeding & 63 & 42.0 \\
\hline Shrunken & 29 & 19.3 \\
\hline \multicolumn{3}{|l|}{ Pain with cold food } \\
\hline Yes & 133 & 88.7 \\
\hline No & 17 & 11.3 \\
\hline \multicolumn{3}{|l|}{ Pain with hot food } \\
\hline Yes & 87 & 58.0 \\
\hline No & 63 & 42.0 \\
\hline \multicolumn{3}{|l|}{ Problem with speaking } \\
\hline Yes & 60 & 40.0 \\
\hline No & 90 & 60.0 \\
\hline \multicolumn{3}{|l|}{ Shy and avoid smiling } \\
\hline Yes & 69 & 46.0 \\
\hline No & 81 & 54.0 \\
\hline \multicolumn{3}{|l|}{ Hard chewing of food } \\
\hline Yes & 103 & 68.7 \\
\hline No & 47 & 31.3 \\
\hline \multicolumn{3}{|l|}{ Hard swallowing of food } \\
\hline Yes & 81 & 54.0 \\
\hline No & 69 & 46.0 \\
\hline
\end{tabular}

Table (5): Distribution of elderly regardingelderly attitude toward dental health( $\mathrm{n}=150)$.

\begin{tabular}{|l|l|l|l|l|l|l|}
\hline \multirow{2}{*}{ Attitude toward dental health } & Agree & \multicolumn{2}{l|}{ Sometimes } & \multicolumn{2}{l|}{ Dis agree } \\
\cline { 2 - 8 } & No. & \% & No. & \% & No. & $\%$ \\
\hline \hline Eating sugary food is harmful & 100 & 66.7 & 41 & 27.3 & 9 & 6.0 \\
\hline Dental wash keep it healthy & 121 & 80.7 & 25 & 16.7 & 4 & 27 \\
\hline Think of daily dental wash before bedtime & 79 & 52.7 & 36 & 24.0 & 35 & 23.3 \\
\hline $\begin{array}{l}\text { Think of necessity of visiting dentist with } \\
\text { dental pain }\end{array}$ & 98 & 65.3 & 29 & 19.3 & 23 & 15.3 \\
\hline Healthy teeth means healthy body & 87 & 58.0 & 46 & 30.7 & 17 & 11.3 \\
\hline Milk, cheese, eggs, veg and fruits keep teeth & 95 & 63.3 & 41 & 27.3 & 14 & 9.4 \\
\hline
\end{tabular}


Quality of Dental Care among Elderly InBenha City

\begin{tabular}{|l|l|l|l|l|l|l|}
\hline healthy & & & & & & \\
\hline Peanuts harm teeth & 52 & 34.7 & 56 & 37.3 & 42 & 28.0 \\
\hline Juice, soft drink harm teeth & 51 & 34.0 & 44 & 29.3 & 55 & 36.7 \\
\hline Regular checkup of teeth is necessary & 63 & 42.0 & 42 & 28.0 & 45 & 30.0 \\
\hline Different economic level affect dental health & 71 & 47.3 & 42 & 28.0 & 37 & 24.7 \\
\hline Fast food affect teeth & 131 & 87.3 & 14 & 9.3 & 5 & 3.3 \\
\hline Brushing teeth keep it healthy & 116 & 77.3 & 27 & 18.0 & 7 & 4.7 \\
\hline Dental wash after sugary food is necessary & 81 & 54.0 & 44 & 29.3 & 25 & 16.7 \\
\hline Chang tooth brush every 2m is necessary & 62 & 41.3 & 30 & 20.0 & 58 & 38.7 \\
\hline Increasing tooth wash make it healthier & 80 & 53.3 & 25 & 16.7 & 45 & 30.0 \\
\hline Hot food after cold harm teeth & 147 & 98.0 & 3 & 2.0 & 0 & 0.0 \\
\hline
\end{tabular}

Table (6): Distribution of elderlyregarding their total attitude toward dental health(n=150).

\begin{tabular}{|c|c|c|c|c|c|c|c|}
\hline \multicolumn{2}{|c|}{ Attitude toward dentalhealth } & \multicolumn{2}{|c|}{ Unsatisfactory } & \multicolumn{2}{|c|}{ Satisfactory } & \multirow{2}{*}{$\begin{array}{l}\text { Test } \\
\mathbf{Z}=6.23\end{array}$} & \multirow{2}{*}{$\begin{array}{l}\text { P value } \\
0.001^{* *}\end{array}$} \\
\hline No & $\%$ & 109 & 72.7 & 41 & 27.3 & & \\
\hline Mean & $\pm \mathrm{SD}$ & $40.42 \pm$ & $8.5 \pm$ & 65.75 & 1.92 & St $\mathbf{t}=18.86$ & $0.001 * *$ \\
\hline
\end{tabular}

Table (7): Relation between elderly socio demographic data and their total attitude levels $(\mathrm{n}=150)$.

\begin{tabular}{|c|c|c|c|c|c|c|}
\hline \multirow[b]{2}{*}{$\begin{array}{l}\text { Attitude level } \\
\text { Socio demographic data }\end{array}$} & \multicolumn{2}{|c|}{ Unsatisfactory $(<60 \%)$} & \multicolumn{2}{|c|}{ Satisfactory $(\geq 60)$} & \multirow[t]{2}{*}{ Test } & \multirow[t]{2}{*}{ P value } \\
\hline & No. & $\%$ & No. & $\%$ & & \\
\hline \multicolumn{7}{|l|}{ Age } \\
\hline 65- & 60 & 55.0 & 28 & 68.3 & $\wedge 2.5$ & 0.275 \\
\hline $70 \mathrm{y}-$ & 36 & 33.0 & 11 & 26.8 & & \\
\hline $75+$ & 13 & 11.9 & 2 & 4.9 & & \\
\hline \multicolumn{7}{|l|}{ Sex } \\
\hline Male & 68 & 62.4 & 36 & 87.8 & 9.05 & $0.003^{* * *}$ \\
\hline Female & 41 & 37.6 & 5 & 12.2 & & \\
\hline \multicolumn{7}{|l|}{ Education level } \\
\hline Read and write & 67 & 61.5 & 9 & 22.0 & 54.71 & $0.001 * *$ \\
\hline Primary education & 33 & 30.3 & 5 & 12.2 & & \\
\hline Secondary education & 7 & 6.4 & 10 & 24.4 & & \\
\hline University education and more & 2 & 1.8 & 17 & 41.4 & & \\
\hline \multicolumn{7}{|l|}{ Working } \\
\hline Yesworking & 7 & 6.4 & 10 & 24.4 & 9.57 & $0.002 * *$ \\
\hline Not working & 102 & 93.6 & 31 & 75.6 & & \\
\hline \multicolumn{7}{|l|}{ Monthly income } \\
\hline Enough and more & 7 & 6.4 & 7 & 17.1 & 13.16 & $0.001 * *$ \\
\hline Just enough & 78 & 71.6 & 34 & 82.9 & & \\
\hline Not enough & 24 & 22.0 & 0 & 0.0 & & \\
\hline \multicolumn{7}{|l|}{ Residence } \\
\hline Rural & 77 & 70.6 & 17 & 41.5 & 10.84 & $0.001 * *$ \\
\hline Urban & 32 & 29.4 & 24 & 58.5 & & \\
\hline \multicolumn{7}{|l|}{ Housing type } \\
\hline Separate & 75 & 68.8 & 29 & 70.7 & 0.052 & 0.82 \\
\hline Shared & 34 & 31.2 & 12 & 29.3 & & \\
\hline
\end{tabular}

Table (8): Differences between knowledge levels regarding socio demographic data

\begin{tabular}{|c|c|c|c|c|c|c|}
\hline \multirow{2}{*}{$\begin{array}{l}\text { knowledge } \\
\text { level } \\
\text { Socio demographic data }\end{array}$} & \multicolumn{2}{|c|}{$\begin{array}{l}\begin{array}{l}\text { Unsatisfactory }(<60 \%) \\
(\mathrm{N}=9)\end{array} \\
\end{array}$} & \multicolumn{2}{|c|}{$\begin{array}{l}\begin{array}{l}\text { Satisfactory }(\geq 60) \\
(\mathrm{N}=141)\end{array} \\
\end{array}$} & \multirow[t]{2}{*}{ FET } & \multirow[t]{2}{*}{ P value } \\
\hline & No. & $\%$ & No. & $\%$ & & \\
\hline \multicolumn{7}{|l|}{$\overline{\text { Age }}$} \\
\hline $65-$ & 4 & 44.4 & 84 & 59.6 & 2.13 & 0.323 \\
\hline $70 \mathrm{y}-$ & 3 & 33.3 & 44 & 31.2 & & \\
\hline $75+$ & 2 & 22.2 & 13 & 9.2 & & \\
\hline \multicolumn{7}{|l|}{ Sex } \\
\hline Male & 4 & 44.4 & 100 & 70.9 & 1.68 & 0.195 \\
\hline Female & 5 & 55.6 & 41 & 29.1 & & \\
\hline \multicolumn{7}{|l|}{ Education level } \\
\hline Read and write & 5 & 55.6 & 71 & 50.4 & 1.49 & 0.713 \\
\hline Primary education & 2 & 22.2 & 35 & 24.8 & & \\
\hline Secondary education & 0 & 0.0 & 17 & 12.1 & & \\
\hline University education and more & 2 & 22.2 & 18 & 12.8 & & \\
\hline
\end{tabular}


Quality of Dental Care among Elderly InBenha City

\begin{tabular}{|l|l|l|l|l|l|l|}
\hline Working & & & & & \\
\hline Yes & 1 & 11.1 & 16 & 11.3 & 0.0 \\
\hline No & 8 & 88.9 & 125 & 88.7 & 1.0 \\
\hline Monthly income & & & & & \\
\hline Enough and more & 1 & 11.1 & 13 & 9.2 & 0.388 & 1.0 \\
\hline Just enough & 7 & 77.8 & 105 & 74.5 & \\
\hline Not enough & 1 & 11.1 & 23 & 16.3 & \\
\hline Residence & & & & & \\
\hline Rural & 5 & 55.6 & 89 & 63.1 & & 0.01 \\
\hline Urban & 4 & 44.4 & 52 & 36.9 & & 0.921 \\
\hline Housing type & & & & 67.4 & \\
\hline Separate & 9 & 100 & 95 & 32.6 & 2.84 \\
\hline Shared & 0 & 0.0 & 46 & 0.09 \\
\hline
\end{tabular}

Table (9): Relation between practice levels regarding socio demographic data.

\begin{tabular}{|c|c|c|c|c|c|c|}
\hline \multirow{2}{*}{$\begin{array}{r}\text { Practice level } \\
\text { Socio demographic data }\end{array}$} & \multicolumn{2}{|c|}{ Unsatisfactory $(<60 \%)$} & \multicolumn{2}{|c|}{ Satisfactory $(\geq 60)$} & \multirow[t]{2}{*}{ FET } & \multirow[t]{2}{*}{ P value } \\
\hline & No. & $\%$ & No. & $\%$ & & \\
\hline \multicolumn{7}{|l|}{ Age } \\
\hline $65-$ & 68 & 59.1 & 20 & 57.1 & 0.247 & 0.958 \\
\hline $70 y-$ & 36 & 31.3 & 11 & 31.4 & & \\
\hline $75+$ & 11 & 9.6 & 4 & 11.4 & & \\
\hline \multicolumn{7}{|l|}{ Sex } \\
\hline Male & 77 & 67.0 & 27 & 77.1 & $\mathrm{X}^{2}=1.31$ & 0.252 \\
\hline Female & 38 & 33.0 & 8 & 22.9 & & \\
\hline \multicolumn{7}{|l|}{ Education level } \\
\hline Read and write & 61 & 53.0 & 15 & 42.9 & 2.42 & 0.504 \\
\hline Primary education & 27 & 23.5 & 10 & 28.6 & & \\
\hline Secondary education & 11 & 9.6 & 6 & 17.1 & & \\
\hline $\begin{array}{l}\text { University education and } \\
\text { more }\end{array}$ & 16 & 13.9 & 4 & 11.4 & & \\
\hline \multicolumn{7}{|l|}{ Working } \\
\hline Yes & 16 & 13.9 & 1 & 2.9 & 2.26 & 0.133 \\
\hline No & 99 & 86.1 & 34 & 97.1 & & \\
\hline \multicolumn{7}{|l|}{ Monthly income } \\
\hline Enough and more & 12 & 10.4 & 2 & 5.7 & 0.595 & 0.806 \\
\hline Just enough & 85 & 73.9 & 27 & 77.1 & & \\
\hline Not enough & 18 & 15.7 & 6 & 17.1 & & \\
\hline \multicolumn{7}{|l|}{ Residence } \\
\hline Rural & 77 & 67.0 & 17 & 48.6 & $\mathrm{X}^{2}=3.88$ & $0.049 *$ \\
\hline Urban & 38 & 33.0 & 18 & 51.4 & & \\
\hline \multicolumn{7}{|l|}{ Housing type } \\
\hline Separate & 77 & 67.0 & 27 & 77.1 & $\mathrm{X}^{2}=1.31$ & 0.252 \\
\hline Shared & 38 & 33.0 & 8 & 22.9 & & \\
\hline
\end{tabular}

Figure(2): Mean $\pm \mathrm{SD}$ of knowledge, attitude and practice of the studied group

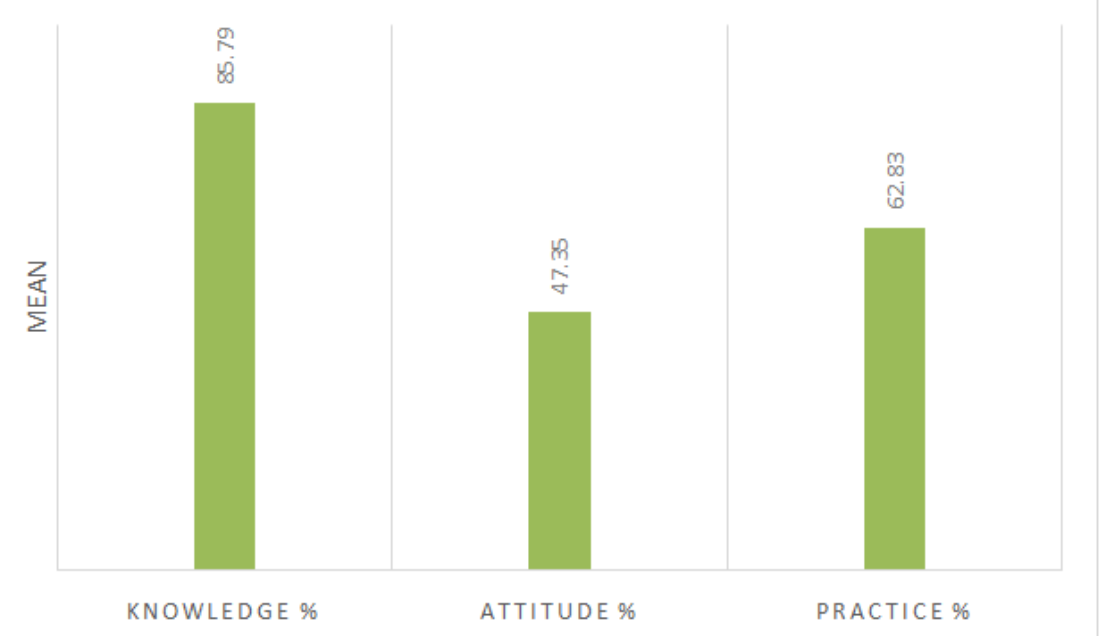




\section{Discussion}

Oral health can be defined as having a comfortable and functional dentition that allows individuals to continue their social role; it is integral to general health, and essential for well-being. Oralhealth is vital to the general health. The mouth reflects a person's health and well-being throughout life. Oral diseases can have an impact on many aspects of general health and health conditions can intern have an impact on oral health. Good oral health is an essential part of daily living. Poor oral health is closely linked to economic deprivation, social exclusion and cultural difference. Emerging evidence has shown a strong link between the effects of oral disease and general health. The mouth is the gateway to the rest of the body. Oral disease is associated with systemic disease such as cardiovascular disease, stroke, respiratory infections, diabetes, and nutritional problems [23].The aim of the present study was to determine quality of dental care among elderly in Benha City.

Regarding age, the result of the present study revealed that more than half of the studied sample their age ranged from 65 to less than 70 years old, more than two thirds were male (Table 1). This result was contradicted with the results of the study by [24]. Who studied "Factors contributing to tooth loss among the elderly".They revealed that more than half were female. This may be attributed to pregnancy and childbearing period. As regarding educational level the result of the present study revealed that more than half had low education.This result was similar to [25].Who studied "Factors contributing to tooth loss among the elderly". He revealed that more than half of studied sample have low education. This may be the elderly ignore and no care of education. Considering dental problems, more than three fifth of studied sample had loss of teeth as a dental problem (Figure1). This result was similar to [26].who studied"Impact of dental care on oral health-related quality of life and treatment goals among elderly adults". They revealed that the more percent's of studied sample had tooth loss. This result also agrees with the results of the study by [27]. Who studied "Dental demographics and metrics of oral disease in the aging Australian population". He found that the most of the studied sample had tooth loss. This may be because aging process.

Considering the knowledge of studied sample about dentalcaries, the result of the present study revealed that more than two third knew about what is the meaning of dental caries (Table 2). This result was contradicted with[28].Who studied "Dental caries among the elderly in Norway". They revealed that the most of the studied sample didn't know what dental caries is. This discrepancy between the two results may be related to the reason that, dental caries is the most common dental problem experienced by elderly.

Regarding cause of dental caries, the result of the present study revealed that about three quarters of the studied sample knew the cause of caries and how the protect teeth from dental caries (Table 2). This result disagreed with [29]. Who studied "dental care knowledge and practice of Group of Health workers in Benin city, Nigeria".They revealed that the most of studied sample had good knowledge about dental caries, causes of caries, protect teeth from dental caries this may by poor knowledge of elderly about dental caries. Considering foods causing dental pain the result of the present study revealed that less than half of studied sample say that all foods cause dental pain (Table 2). This result disagreed with [30]who studied "Prevalence and Correlates of Dental Caries in an Elderly Population in Northeast" they revealed that the sugary food only cause dental pain. This may be because level of education of elderly they knowing all foods cause dental pain.

Considering practices toward treating dental diseases, the result of the present study revealed that more than half washing their teeth once daily by using dental brush (Table 3).This result was contradicted with [31]who studied "oral health of older adults".They revealed that one third of studied sample wash the teeth twice daily. Also more than half visit a dentist since one years ago and less than two third visiting dentist in case of dental problem (Table 3). This result was similar to [32]who studied"Knowledge and practice of traditional healers in oral health in the Bui Division". He revealed that less thantwo third of patients visit the clinic only when they have pain or an emergency dental problem. This may be dental services are completely absent and the distance to the nearest dental facility is very long.

Regarding time of dental wash, the result of the present study revealed that more than one third washing their teeth before sleep (Table 3). This result was contradicted with[33]who studied "Oral Health Status of the Elderly at Tonga". He revealed that three quarters brush in the morning only. This may be related that elderly think that the mouth is filled with bacteria at night.

Regarding elderly attitude towards dental health the result of the present study revealed that, more than two third agree that eating sugary food is harmful to teeth (Table 5). This finding was similar to the majority of sample had agreed that dental wash keep teeth healthy and take away fast food affect and harm teeth. The most majority had agreed that hot food after cold food harm teeth, more than half agreed that dental wash after sugary food is necessary and increasing washing teeth make it healthier, less than half agreed that the regularity of checking up of teeth is necessary and agreed that change tooth brush every two month is necessary. Also the result of the present study revealed that, less than half agreed that different economic level affect dental health this finding was similar to [34]who studied "Satisfaction among university dental clinic patients in Finland".He revealed thatmore than one third agree thatvisited a dentist as recommended by friends and neighbors this shows the importance of social environment for choosing of dentist and different economic level affect dental health 
(Table 5). The result of the present study revealed that, less than half agreed that the regularity of checking up of teeth is necessary and agreed that change tooth brush every two month is necessary (Table 5). This finding was similar to[35]. Who studied "Public attitude towards dentists and dental services in Bangalore city" he revealed that half of studied sample agreed that the regularity of checking up of teeth is necessary this may be awareness of the elderly population regarding the role played by regular dental visits in preventing dental diseases.

Consideringthe relation between attitude levels and socio demographic characteristics the result of the present study revealed that, There were statistical significant difference between elderly'ssocio demographic characteristics and total score of attitude about oral health (Table 7). This result was similar to the results of [36]. Who studied "Assessment of Knowledge andAttitudes to Preserve Oral Health among Older People Aged 60+ inFYROM". They revealed that there were statistical significant difference between elderly's socio demographic characteristics and attitude. This may because this is due to the degree of education of elderly.

Regarding relation between knowledge and socio demographic characteristics; the result of the present study revealed that there were no statistical significant difference between elderly's knowledge and socio demographic characteristics (Table 8). This result was disagreeing with [37]who studied "Oral health-related quality of life". They revealed that there was statistical significant difference between elderly's socio demographic characteristics knowledge and total score knowledge about oral health.

Considering the relation between practice levels and socio demographic characteristics the result of the present study revealed that were no satisfactory statistical significant difference between elderly's socio demographic characteristics practice and total score of practice (Table 9). This result was consistent to [30]. They revealed that there were no statistical significant difference between studied sample and practice. This may be because of ignorance, neglect of practice.

\section{Conclusion}

- The results of the present study revealed that, , $44.7 \%$ have wet mouth condition, $61.3 \%$ had dental loss as dental disease, $50 \%$ had gum inflammation, $43.3 \%$ had broken teeth, $34.7 \%$ had dental caries and $21.3 \%$ have discoloration of teeth.

- There were statistically significant relation between the studied elderly's attitudeand socio-demographic data but, there was no statistically significant relation between studied elderly's knowledge, practice and sociodemographic data.

\section{Recommendation}

1- Health education program should be conducted at out-patient clinics, to improve knowledge, practice and quality of life of the elderly people with oral disease.

2- Health education program for elderly regarding importance oral health care and oral health care practice for empowering elderly to understand the change of the elderly's attitude rather than providing only knowledge.

3- Further research about obstacles of elderly's oral health.

\section{References}

[1] Harris NO. 6th ed. New York: Prentice Hill; (2013): Primary Preventive Dentistry.

[2] World Health Organisation (2006): Oral health in ageing societics: integration of oral health and general health. 2006, Geneva: World Health Organisation.

[3] Sergievpv, Dontsova OA, Berezkin GV (2015): Theories of aging :an ever- evolving field . Acta Naturae. g-18 PMID: 25926998 www.ncbi-nlm.nih.gov/pubmed/25926998.

[4] Sanders AE., Slade GD., Carter KD and Stewart JF (2004): Trends in prevalence of complete tooth loss among Australians, 19792002. Aust N Z J Public Health;28:45-50.

[5] Rockville, MD., (2010): U.S. Department of Health and Human Services. Oral Health in America: National Institute of Dental and Craniofacial Research, National Institutes of Health, U.S. Department of Health and Human Services.

[6] Lamy, M., Mojon, P., Kalykakis, G., Legrand, R., and Budtz-Jorgensen (2009): Oral status and nutrition in the institutionalized elderly.J Dent 27: pp. 443-448.

[7] Lanspa NJ, Jones P, Prown S, Dean N. (2013): Mortality, morpidity, and disease severity of patients with aspiration pneumonia. JH osp Med. Feb. 8 (2): 83-92.

[8] Allen PF (2003): Assessment of oral health related quality of life. Health Oual Life Outcomes 2003: 1:40http://onlinelibrary.wiley.com/doi/10.1111/j.1532-849X.2009.00518.x/full.

[9] Abd Allah, M.(2012): The Effect of urinary Incontinence on Quality of life for Elderly people in Benha City, Master Thesis, Faculty of nursing, Benha University, p32.

[10] Costanza,R., Fisher, B., Ali, S., Beer C., and Boumans, R.(2008): An Integrative approach to quality of life measurement, research, and policy. Online. URV: http.// sapiens. Revues org/index $169 \mathrm{html}$.

[11] Besdine, v. and Blane, D. (2013): Quality of life in older ages, oxford journals, 85(1):113-126.

[12] Centers for Disease Control and Prevention (CDC),(2014): Health related quality of life and well-Peing, Available at http://www.cdc. Gov/healthy living /index. Html.

[13] World Health Organisation. (WHO), (2014): Definition of an older or Elderly person, Anailableat:http://www.who.int/health info/syrvey/ageing defnolder/en/.Accessed on Decembr2015.

[14] Panchbhai AS.(2012): Oral health care needs in the dependant elderly in India. Indian J Palliat Care. 2012;18(1):19-26. [PMC free article] [PubMed.

[15] Abdalh, C.R., Pickard, R.,B. (2008): Dental hygienists and long-term care.J Dent Hyg 72(2): pp. $27-33$.

[16] Carr AB (2014): (expert opinion). Mayo Clinic, Rochester, Minn. Oct. 22

DOI: 10.9790/1959-0604016476 www.iosrjournals.org 75 | Page 
[17] Felton D, et al. (2011): Evidence-based guidelines for the care and maintenance of complete dentures: A publication of the American College of Prosthodontists. Journal of the American Dental Association. 142:1S.

[18] Dentures. NHS (2014): Choices. http :// www. nhs.uk/ conditions/ dentures/ Pages/Introduction.aspx. Accessed Oct. 14.

[19] Vincent G.K. and Velkoff, V.A. (2010): The next four decades. The older population inthe UnitedStates: 2010-2050.Current Population Report 25-1138.

[20] Wunderlich, S., Bia, Y., and Piemonte J. (2011): Nutrition risk factors among home delivered and congregate meal participants: Need for enhancement of nutrition education and counseling among home delivered meal participants. Journal ofNutrition, Health, and Aging 15(9) 768-772.

[21] EL.Katatney, E. (2009): Same old, same old Egypt today in 2050, A fifth of Egyptions will be Age 60 and older. How will the country Accovmodatetsdiging population. Available @ http://etharelkatantney. Word prss com category Egypt-today pa. ge/3/.

[22] Dlaney, T. (2004): likert scale Isix sigma. Colorado. P.1. Available on: www.yahoo.com.

[23] Jukka H. Meurman and Lisa Grönroos (2010): Oral and dental health care of oral cancer patients: hypo-salivation, caries and infections Oral Oncology, Vol 46, Issue 6, June 464-467.

[24] Zuhair S. Mohammed Alasqaha., and Athena (2014): Factors contributing to tooth loss among the elderly: A cross sectional study: Papas http://dx.doi.org/10.1016/j.sdj.11.002.

[25] Aladmawya, (2014): Factors contributing to tooth loss among the elderly: A cross sectional study http://dx.doi.org/10.1016/j.sdj.11.002.

[26] Dl Gagliardi, GD., Slade, AE., and sanders. (2008): Impact of dental care on oral health-related quality of life and treatment goals among elderly adults. DOI: 10.1111/j.1834-7819.00005, accessed on 1/2/2017.

[27] Mshopcraft, (2015): Dental demographics and metrics of oral disease in the aging Australian population Dol : 10.1111 adj.12279.

[28] Henriksen BM, Ambjornsen E, Axell T (2004): Dental caries among the elderly in Norway. ActaOdontolScand 62 (2) 75-81.

[29] Ehizele A O, Azodo CC, Ehigiator O, Ezeja EB (2012): Misconceptions about oral health among group of Nigeian. NiJ Dent J.20:37-40.

[30] Lu Liu, Ying Zhang, Wei Wu, Min Cheng, Yan Li, Ruibo Cheng (2013): Prevalence and Correlates of Dental Caries in an Elderly Population in Northeast https://doi.org/10.1371/journal.pone.0078723.

[31] Suominen-Taipale L, Nordblad A, Vehkalahti M, Aromaa A (eds.) (2008): Oral Health in the Finnish AdultPopulation. Health 2000 Survey. Publications of the National Public Health Institute B 25/2008. Helsinki :Hakapaino Oy, pp 205.

[32] Agbor and S. Naidoo (2011): "Knowledge and practice of traditional healers in oral health in the Bui Division, Cameroon," Journal of Ethnobiology and Ethnomedicine, vol. 7, article 6.

[33] Macqueron, (2013): L'étatbucco-dentairedans les EHPAD en France [Thesis in Dental Surgery].

[34] Alvesalo I, Uusi-Heikkilä Y. (2009): Use of services, care-seeking behavior and satisfaction among university dental clinic patients in Finland. Community Dent Oral Epidemiol 12:297-302

[35] Newman J, Gift H.(2014): Regular pattern of preventive dental services - A measure of access. SocSci Med 1992;35:9971001. http://www.jiaphd.org/article.asp?issn=2319-5932.

[36] Šapurić, / F. Tozja (2015): Assessment of Knowledge and Attitudes to Preserve Oral Health among Older People Aged 60+ in FYROM/DOI: https://doi.org/10.1515/bjdm-2015-0030.

[37] Samk. S. Ng, W. Keung leung. (2007): A community study on the relationship of dental anxiety with oral health status and oral health-related quality of life. Dol: 10.1111/j.1600-0528.00412.x.

Magda M. Mohsen. "Quality of Dental Care among Elderly in Benha City." IOSR Journal of Nursing and Health Science (IOSR-JNHS) 6.4 (2017): 64-76. 